\title{
Model Data Mining Time Series Untuk Prediksi Profitabilitas Perusahaan
}

Time Series Data Mining Model For Company Profitability Prediction

\author{
Muksan Junaidi*1, Adhika Pramita Widyassari ${ }^{2}$ \\ ${ }^{1,2}$ Sekolah Tinggi Teknologi Ronggolawe Cepu; Jl. Kampus Ronggolawe Blok B No.1, \\ Mentul Cepu, Blora 58315, Indonesia, Telp.0296422322. \\ ${ }^{3}$ Jurusan Teknik Elektro, Konsentrasi Teknik Informatika, STTR, CEPU

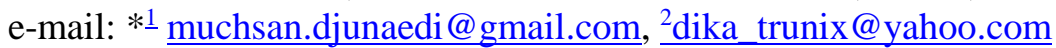

\begin{abstract}
Abstrak--Profitabilitas merupakan rasio keuangan yang memperlihatkan kemampuan operasional perusahaan untuk menghasilkan laba operasi melalui modal sendiri. Untuk melihat kondisi kemampuan operasional perusahaan pada masa mendatang, bisa dilakukan dengan memprediksi nilai rasio tersebut. Teknik dalam menangani masalah prediksi ini adalah menggunakan model data mining. Penelitian ini bertujuan mengembangkan aplikasi prediksi profitabilitas keuangan perusahaan melalui model data mining neuro-fuzzy ANFIS dengan data time series. Data penelitian adalah data sekunder bersifat kuantitatif dari wibe site www.idx.co.id. Populasi data dari perusahaan emiten LQ45 di Bursa Efek Indonesia(BEI) tahun 2011-2016 berjumlah 45 perusahaan. Pemrosesan awal menghitung nilai rasio keuangan perusahaan yang akan dipakai sebagai data input pada model ANFIS. Simulasi dan evaluasi model menggunakan aplikasi GUI program Matlab. Perbandingan antara perhitungan rasio profitabilitas tahun yang di prediksi dengan nilai dari model ANFIS. Hasil akhir menunjukkan bahwa nilai model ANFIS sangat optimal, efisien, konsisten dan paling mendekati rata-rata nilai rasio tahun yang di prediksi sebesar $9.95 \%$ pada fungsi keanggotaan Segitiga. Sedang hasil prediksi tiga fungsi keanggotaan lainnya Trapesium, G-bell dan Gauss kurang optimal.
\end{abstract}

\section{Kata kunci : ANFIS; Neuro-Fuzzy; Prediksi; Profitabilitas.}

Abstract--Profitability is a financial ratio that shows a company's operational ability to generate operating profits through its own capital. To see the future of operational company's capability condition, can be predicted using the value of the ratio with a data mining model. The aims of this studies to develop a prediction application of corporate financial profitability using the ANFIS neuro-fuzzy data mining model with time series data. The data use on this Research is secondary quantitative data from the website www.idx.co.id. Data population from LQ45 issuers in the Indonesia Stock Exchange (BEI) 2011-2016 from 45 companies. And calculates of Initial processing the value of the company's financial ratios using ANFIS model. simulation and evaluation model using the GUI application Matlab program. Comparison between the predicted profitability ratios calculation with the values from the ANFIS model. The final results showed the ANFIS model value is very optimal, efficient, consistent and have the predicted value of the year ratio $9.95 \%$ in the Triangle membership function. While the prediction results of the three other membership functions Trapezoid, G-bell and Gauss are less than optimal.

\section{Keyword : ANFIS; Neuro-Fuzzy; Prediction; Profitability.}

\section{Pendahuluan}

Kondisi perekonomian Indonesia tahun 2014 turun melambat hingga akhir 2016 berfluktuasi. Nilai tukar rupiah terhadap dollar AS melemah dilevel 13,369. Hal ini sangat berdampak pada perdagangan saham di Bursa Efek Indonesia(BEI). Memasuki quartal dua, 2017 rupiah masih stagnan dilevel 13,391. 
Perkembangan pasar modal akan memberi alternatif investasi tidak terbatas di sektor "aset riil" dan perbankan, investor bisa menanamkan dana di pasar modal. Satu saham BEI yang diminati investor adalah saham LQ45. Penetapan saham LQ-45 berdasarkan likuiditas dan $90 \%$ dari rata-rata kapitalisasi pasar [1].

Data website IDX, indeks LQ45 tahun 2016, nilai deviden cash dan volume perdagangan menurun hingga akhir 2015. Nilai profitabilitas ROE tahun 2014 menurun dibanding 2013 dari $22.72 \%$ menjadi $21.66 \%$, selanjutnya 2015 turun lagi menjadi $16.11 \%$. Rasio ROE ini dipakai untuk mengukur keberhasilan operasional perusahaan dalam menghasilkan laba bagi para pemodal, [2]. Rasio ROE sering difungsikan untuk melihat dan memprediksi kondisi keuangan terbatas pada akhir tahun saja. Bagaimana mengembangkan aplikasi prediksi profitabilitas perusahaan untuk beberapa tahun kedepannya dengan data rasio ROE masa lalu sehingga hasilnya lebih baik optimal, terinci, dan konsisten.

Prediksi profitabilitas dipakai sebagai peringatan dini tentang kondisi keuangan perusahaan, hal ini sangat dibutuhkan oleh para investor dan manajemen dalam mengelola perusahaan. Dengan memakai model data mining neuro-fuzzy ANFIS dapat memprediksi kondisi profitabilitas perusahaan beberapa tahun kedepan. Namun demikian, hasil prediksi model ini tergantung pada banyaknya data input yang digunakan. Peneliti model ANFIS sebelumnya : Dinesh C. S. Bish, et al. (2011)[3],meneliti Pemodelan Debit menggunakan Adaptif Neuro-Fuzzy Inference System. Ruminta, (2012) [4], meneliti model dinamika temporal dan memprediksi debit air di atas aliran sungai Citarum dengan metode ANFIS. Ahmad Yani, dkk. (2012) [5], penerapan ANFIS untuk pengenalan sinyal EKG. Bagus Fatkhurrozi, dkk. (2012)[6] , penggunaan (ANFIS) untuk menentukan status aktivitas gunung merapi. Ouamri Bachir, at el. (2012)[7] , pengunaan ANFIS untuk kontrol puma 600 lengan robot. Indah Puspitasari, dkk. (2013) [8] , membandingkan akurasi metode BPNN dan ANFIS dalam melakukan prediksi cuaca. Hasil model ANFIS ini tingkat akurasinya baik, konsisten, optimal, fleksibel, stabil, efektif, dengan nilai kesalahan kecil.
Penggunaan inferensi fuzzy model ANFIS Tagaki-Sugeno-Kang (TSK) orde satu sangat sederhana proses komputasinya. Atas dasar itu tujuan penelitian ini adalah pengembangan aplikasi model data mining neuro-fuzzy ANFIS untuk prediksi profitabilitas perusahaan (studi kasus: perusahaan di BEI emiten LQ45 tahun 2011-2016).

\section{LANDASAN TEORI}

\section{Investasi Pasar Modal}

Pasar Modal adalah aktifitas yang berhubungan dalam penawaran umum dan perdagangan efek. Pasar Modal menyediakan beberapa alternatif investasi bagi para pemodal dan alternatif investasi lain. Pasar Modal sebagai penghubung investor dengan pihak perusahaan dan instansi pemerintah melalui instrumen perdagangan keuangan antar lain : obligasi, saham dan lainlain. Pembinaan, pengaturan dan pengawasan Pasar Modal di Indonesia oleh Badan Pengawas Pasar Modal (BAPEPAM) bertanggung jawab langsung pada Menteri Keuangan.

\section{Profitabilitas Return On Equity(ROE)}

Profitabilitas menurut Niswonger dkk [9], adalah kemampuan operasional perusahaan untuk mendapatkan laba, berhubungan dengan pendapatan dari penjualan, total aktiva dan modal. Profitabilitas berfokus pada hasil operasional dan sumber daya perusahaan yang tersedia serta tergantung pada efisiensi dan efektifitas operasional yang dilaporkan pada laba-rugi dan sumber daya perusahaan. Profitabilitas yang tinggi akan diminati oleh para investor. Sehingga, besar kecilnya profitabilitas yang dihasilkan oleh perusahaan dapat berpengaruh pada harga saham [10]. Rasio ROE menurut [11] secara matematis dapat dirumuskan sebagai berikut:

ROE $(\%)=($ NIAT/ Equity) $\times 100 \%$, NIAT $=$ Net Income After Tax(laba bersih sesudah pajak) dan Equity $=$ Total modal sendiri.

Ketentuan dari BI No. 6/23/DPNP, 31-Mei2004 menetapkan, bahwa bank-bank yang punya kinerja sehat yaitu angka ROE berkisar $5 \%$ - 12,2\%. Angka ROE > 12\% dikatakan sehat, sebaliknya jika kurang dari $12 \%$ dapat mempengaruhi persepsi para investor. 


\section{Data Time Series}

Data time series adalah sekumpulan data berasal dari waktu ke waktu, seperti harian, mingguan, bulanan, kwartalan, tahunan dan dijadikan sebagai dasar untuk peramalan. Menurut Hanke, et all di dalam [12], Time Series adalah sekumpulan data yang di catat, atau diamati dalam serangkaian tahapan waktu. Kegunaan analisis tersebut adalah untuk melihat perkembangan suatu objek yang di amati dan diteliti dari waktu ke waktu. Nilai data masa lalu hingga waktu ' $t$ ' titik awal prediksi dan waktu prediksi 't $+\mathrm{p}$ '. untuk pemetaan dari titik ' $D$ ' sampai titik ' $\Delta$ ' secara terpisah dirumuskan :

$\mathrm{x}(\mathrm{t}+\mathrm{p})=[\mathrm{x}(\mathrm{t}-(\mathrm{D}-1) \Delta)] \ldots \mathrm{x}(\mathrm{t}-\Delta), \mathrm{x}(\mathrm{t})$

\section{Algoritma Data Mining neuro-fuzzy ANFIS}

Neuro-fuzzy adalah sistem inferensi fuzzy yang dilatih memakai algoritma pembelajaran turunan dari sistem neural network. Neurofuzzy adalah salah satu sistem hybrid didalam soft computing untuk mendapatkan algoritma yang lebih sempurna [13] pada gambar 2.1.

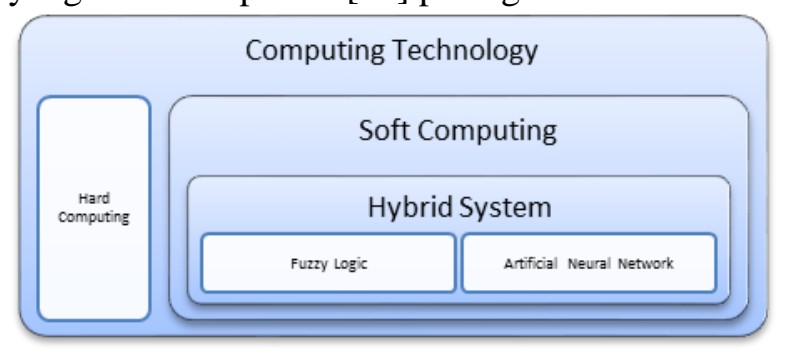

Gambar 2.1 Sistem Hybrid antara Logika Fuzzy dan Neural Network Model neuro-fuzzy salah satunya adalah ANFIS yang diusulkan oleh [14]. Struktur ANFIS yang sudah dikenal yaitu inferensi fuzzy model Takagi-Sugeno-Kang orde satu [15] pada gambar 2.2

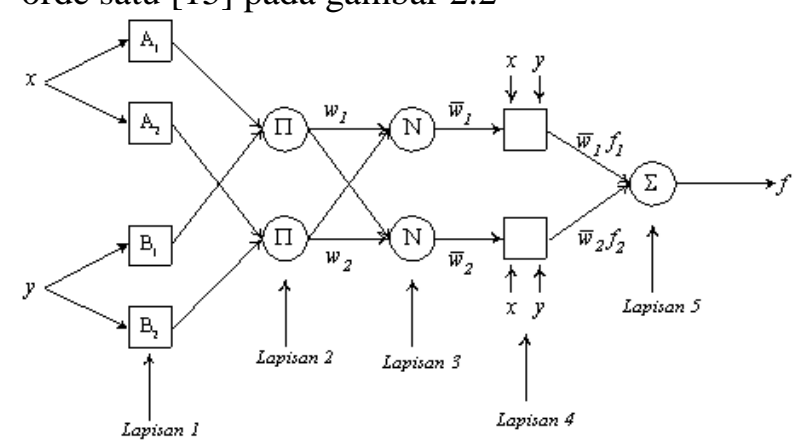

Gambar 2.2 Ilustrasi Struktur Sistem ANFIS

Arsitektur ANFIS terdiri lima lapisan berikut:

Layer-1: layer pertama setelah $\mathrm{x}$ dan y. Setiap node i ke-I di layer ini adaptive node berfungsi ;
$O 1, i=\mu A i(x)$ untuk tiap $i=1,2$, atau

$O 1, i=\mu B i-2(y)$ untuk tiap $\mathrm{I}=3,4$

Menggunakan fungsi, Generalize bell :

$O_{2, i}=w_{i}=\mu_{A i}(x) \times \mu_{B i}(y), i=1,2$

Dimana $\{$ ai , bi, ci $\}$ adalah parameter set.

Layer-2 : Tiap node layer ini, node tetap ditandai sebagai $\Pi$.

$O_{2, i}=w_{i}=\mu_{A i}(x) \times \mu_{B i}(y), i=1,2$

Layer-3 : Tiap node layer ini node tetap sebagai N. Node ke - i mengkalkulasi rasio dari kekuatan rule ke - $\mathrm{i}$.

$$
O_{2, i}=\overline{w_{1}}=\frac{w_{i}}{w_{1}+w_{2}}, i=1,2
$$

Layer 4: Tiap node i layer ini node adaptif menggunakan node fungsi:

$$
o_{4, \mathrm{i}}=\overline{w_{\mathrm{i}}} f_{\mathrm{i}}=\overline{w_{\mathrm{l}}}\left(p_{\mathrm{i}} x+q_{\mathrm{i}} y+r_{\mathrm{i}}\right)
$$

Layer 5 : Node layer ini sebagai $\Sigma$, menghitung keluaran dari lapisan 4

$$
O_{5, i}=\sum \overline{w_{i}} f_{i}=\frac{\sum w_{i} f_{i}}{\sum w_{i}}
$$

\section{Metode}

\section{Pengumpulan Data dan Sample}

Data untuk penelitian adalah data sekunder dari website IDX ; http://www.idx.co.id. Input data dari laporan keuangan neraca dan laba/rugi emiten LQ45 di Bursa Efek Indonesia (BEI) lima tahun 2011-2016 sejumlah 45 perusahaan. Data dihitung untuk mendapatkan rasio profitabilitas ROE periodikal runtun waktu. 


\section{Langkah dan Perancangan Penelitian}

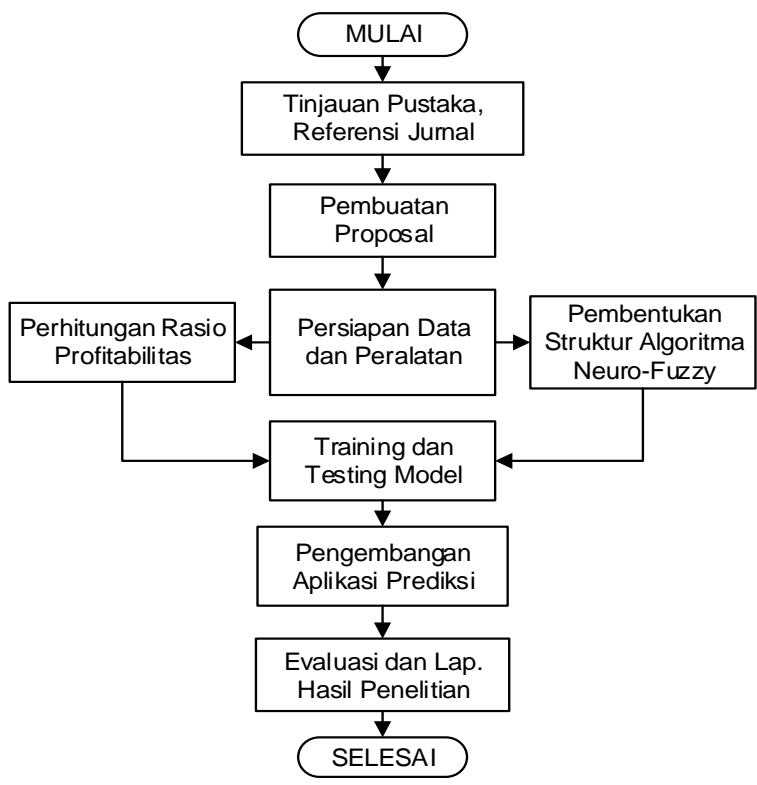

Gambar 3.1 Diagram Alir Rancangan Penelitian

\section{Tinjauan Pustaka, Jurnal Referensi}

Data referensi dari makalah atau jurnal nasional dan internasional sesuai topik penelitian.

\section{Persiapan Data dan Peralatan}

Download data penelitian dari website IDX www.idx.co.id kelompok emiten LQ45 di BEI periode tahun 2011-2016, sejumlah 45 perusahaan.

\section{Pembuatan Proposal}

Menyusun proposal aplikasi prediksi untuk menerapkan algoritma Data mining model ANFIS memakai data runtun waktu.

\section{Pembentukan Struktur Algoritma neuro-} fuzzy

Memakai ANFIS empat (4) MFs fungsi keanggotaan dari GUI Matlab : Segitiga, Trapesium, G-bell dan Gauss. menggunakan empat input data, yaitu kondisi $\mathrm{x}(\mathrm{t}-3), \mathrm{x}(\mathrm{t}-2)$, $\mathrm{x}(\mathrm{t}-1), \quad \mathrm{x}(\mathrm{t})$. Struktur ANFIS dengan 12 masukan fungsi keanggotaan dan 81 role.

\section{Perhitungan Rasio profitabilitas}

Perhitungan dari laporan keuangan laba/rugi dan neraca untuk mendapatkan rasio ROE.

\section{Training dan Testing Model}

Percobaan dan pelatihan model ANFIS menggunakan empat input data nilai profitabilitas ROE berbentuk runtun waktu, masa lalu sampai waktu " $\mathrm{t}$ " seperti : $\mathrm{x}(\mathrm{t}-3)$, $\mathrm{x}(\mathrm{t}-2), \mathrm{x}(\mathrm{t}-1), \mathrm{x}(\mathrm{t})$

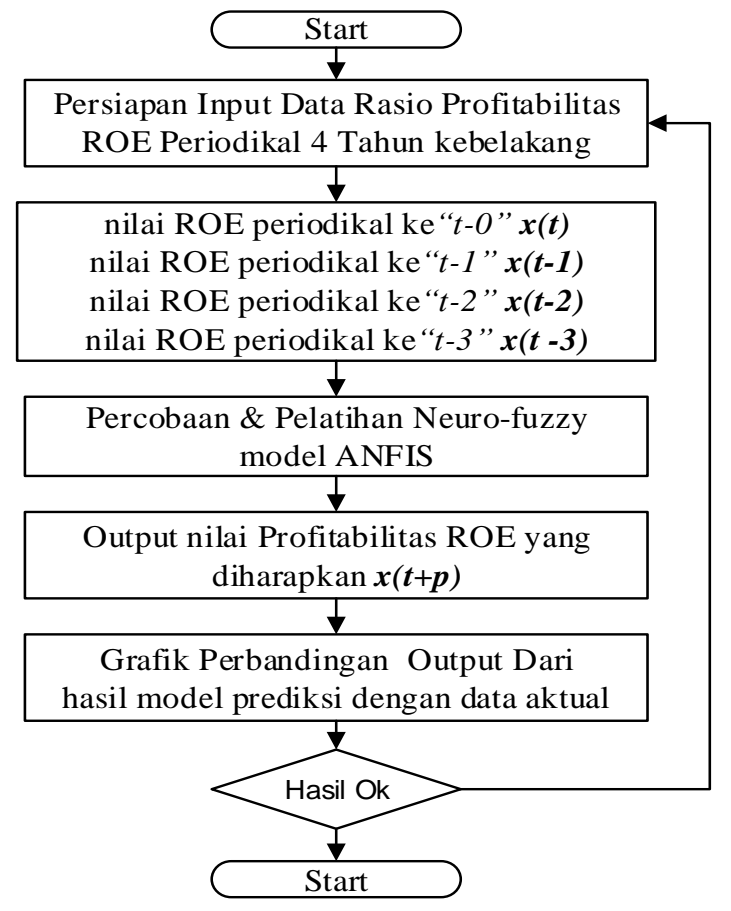

Gambar 3.2 Activity Diagram model ANFIS

\section{Pengembangan Aplikasi Prediksi}

Pengembangan aplikasi prediksi berbasis object oriented programming (OOP) melalui beberapa tahapan analisa, desain, coding dan testing.

\section{Perbandingan Hasil Prediksi}

Penjabaran hasil penelitian di bahas pada tahap berikut dibawahnya.

\section{HASIL}

\section{Pembentukan Struktur ANFIS}

Struktur ANFIS empat masukan, yaitu kondisi $\mathrm{x}(\mathrm{t}-3), \mathrm{x}(\mathrm{t}-2), \mathrm{x}(\mathrm{t}-1), \mathrm{x}(\mathrm{t})$. Terdapat 12 input fungsi keanggotaan dan 81 aturan role. Struktur ANFIS yang digunakan adalah berikut :

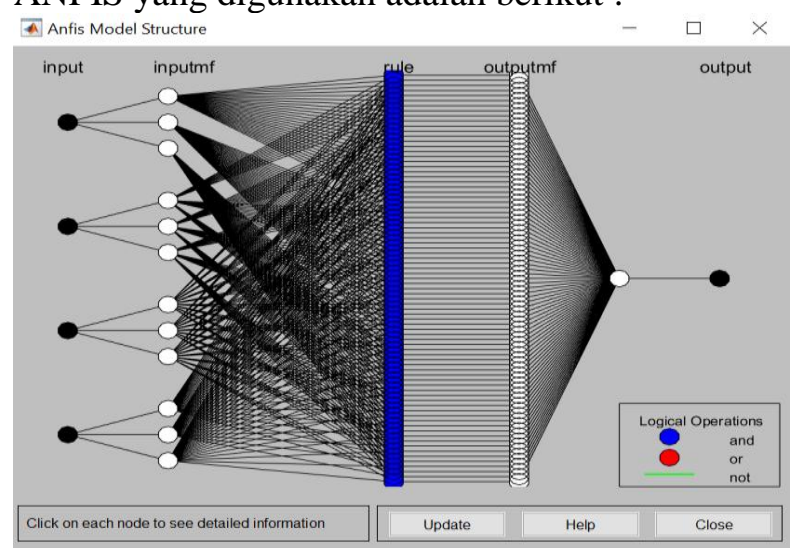

Gambar 3.1 Struktur ANFIS tiga kategori input 


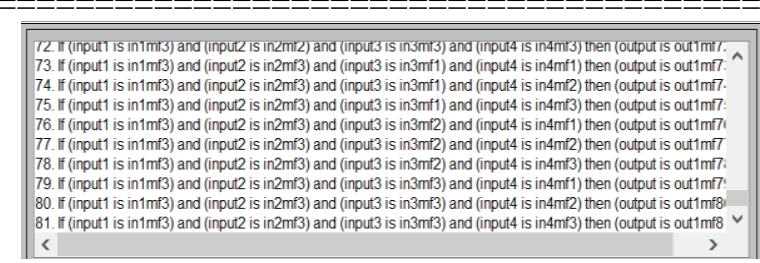

Gambar 3.2 Aturan Fuzzy 81 Role

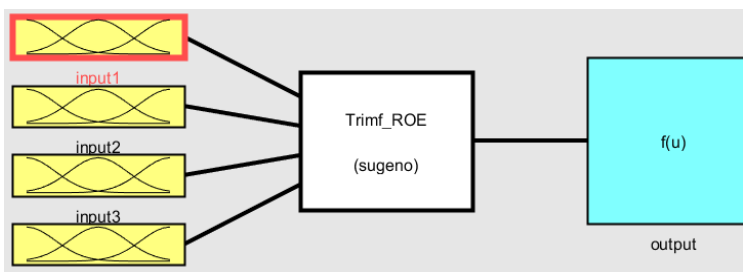

Gambar 3.3 Fuzzy Logic 4 Inputs, 81 Role Sugeno dan 1 Output

\section{Percobaan dan Pelatihan model ANFIS}

Memakai sintak fungsi ANFISEDIT dari matlab untuk menghasilkan ANFIS tipe Sugeno. Diagram alir proses pembentukan adalah berikut ini :

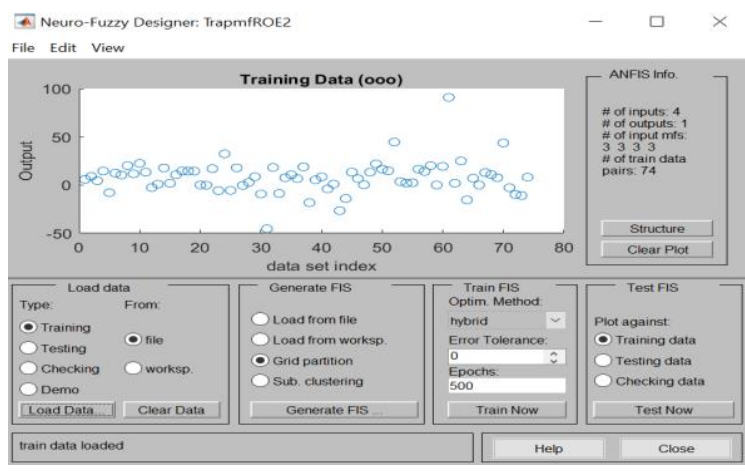

Gambar 3.4 Load Data ROE untuk pembentukan struktur ANFIS

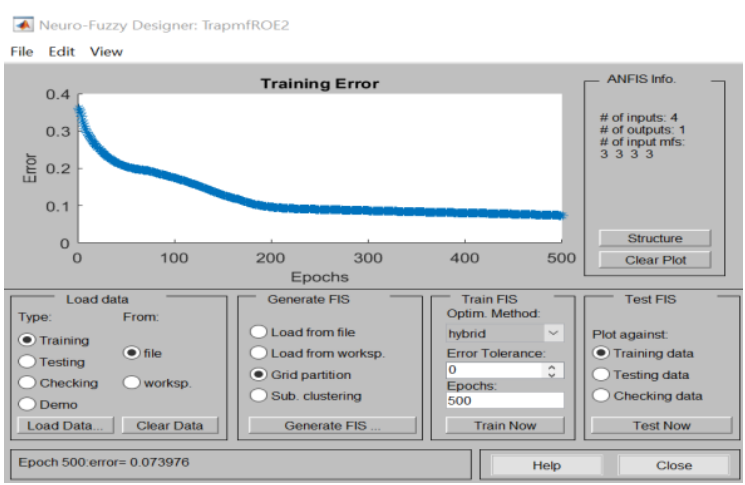

Gambar 3.5 Generate Struktur ANFIS

\section{Input Data ANFIS}

Data Input adalah kondisi perusahaan pada kategori prediksi profitabilitas (tertekan, sehat dan sangat sehat) dengan tiga kategori fungsi keanggotaan Segitiga \& Trapesium:
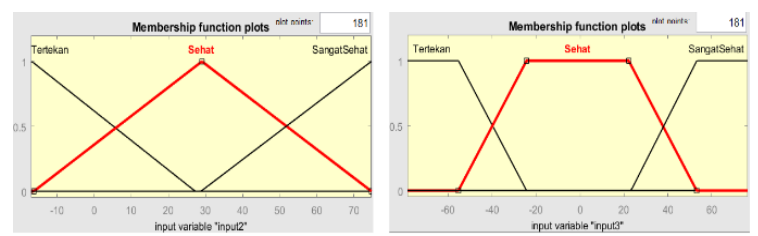

Tiga kategori fungsi keanggotaan Gauss \& Gbell:

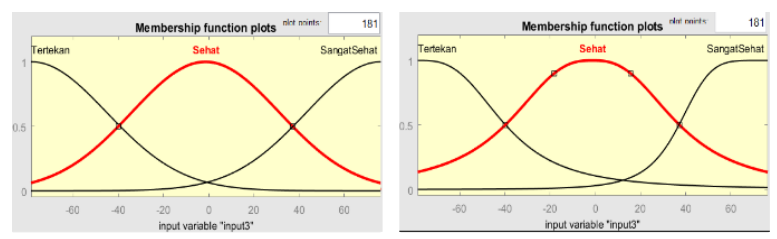

Gambar 3.6 Input model tiga kategori fungsi anggota

\section{Pengembangan dan Desain Software}

Tampilan layar menu program ,input FIS, data runtun waktu kebelakang nilai profitabiltas dari titik ' $t$ '. Dilengkapi dengan output keluaran nilai prediksi dan grafik prediksi.

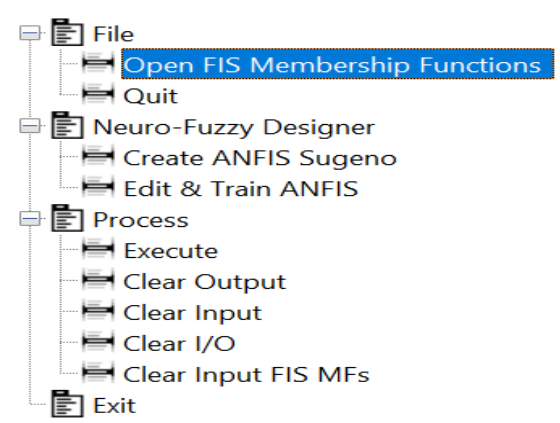

Gambar 3.7 Desain menu utama aplikasi prediksi

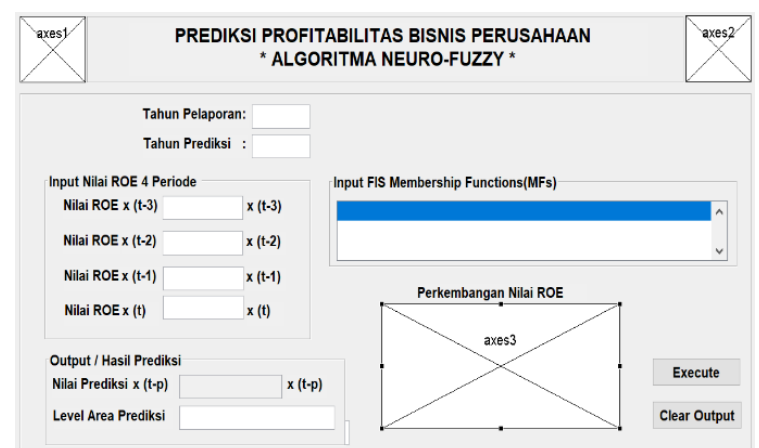

Gambar 3.8 Desain layar utama aplikasi prediksi

\section{Testing Aplikasi Prediksi}

Pengujian aplikasi mengunakan blak box testing yaitu menguji secara functionality 
screen input-output dan menu program aplikasi berikut ini :

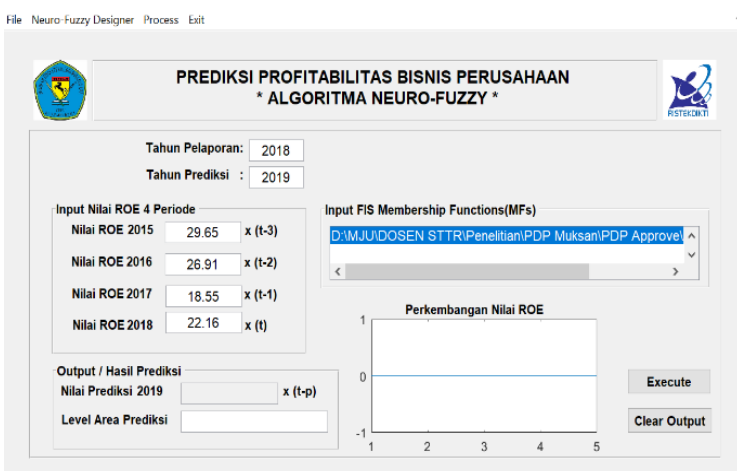

Gambar 3.9 Input Data aplikasi prediksi

Pengujian aplikasi untuk output tiga level area nilai prediksi profitabilitas perusahaan (sangat sehat, sehat dan tertekan) berikut ini :
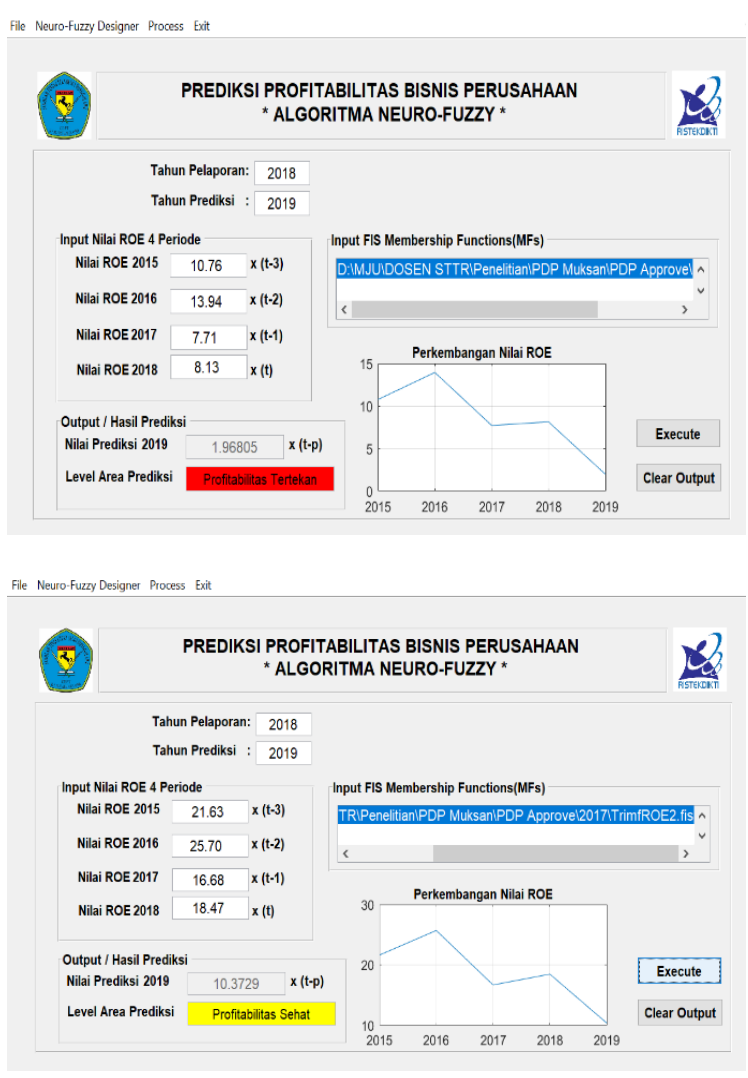

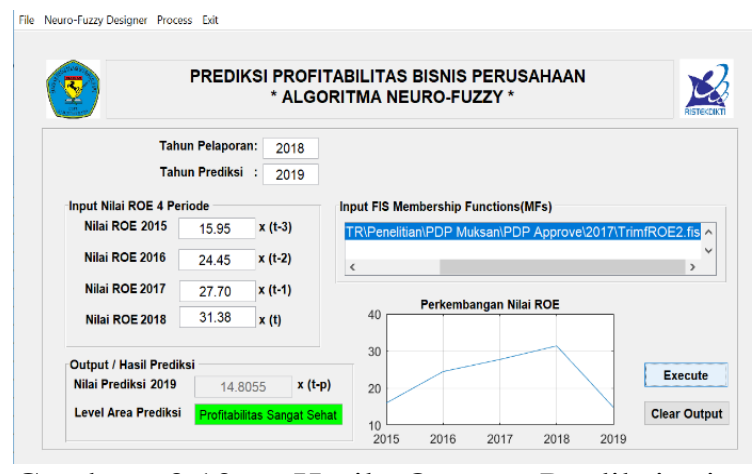

Gambar 3.10 Hasil Output Prediksi tiga kategori

\section{Hasil Pengujian Aplikasi Prediksi}

Ketetapan BI No. 6/23/DPNP, 31-Mei-2004 disebutkan bahwa, bank-bank yang punya kinerja sehat yaitu angka ROE berkisar 5\% $12,2 \%$. Pada uraian profitabilitas dikatakan, bahwa Angka ROE > 12\% kondisi perusahaan sehat, sebaliknya jika kurang dari $12 \%$. Atas dasar hal itu dibentuk range nilai profitabilitas ROE pada area prediksi sebagai berikut ini :

Tabel 2.1 Nilai Profitabilitas pada Area Prediksi

\begin{tabular}{rcc}
\hline No & Rasio Keuangan ROE & Area Prediksi \\
\hline 1 & ROE $<5 \%$ & Tertekan \\
\hline 2 & $12 \%>$ ROE $>=5 \%$ & Sehat \\
\hline 3 & ROE $>12 \%$ & Sangat Sehat \\
\hline
\end{tabular}

Hasil pengujian aplikasi prediksi dengan jumlah 45 sampel data diperoleh berikut ini :

Tabel 2.2 Nilai rata-rata terbaik setiap fungsi keanggotaan

\begin{tabular}{r|r|r|r|r|r|r|r|r|r|}
\multirow{2}{*}{ No. } & $x(t-p)$ & \multicolumn{7}{|c|}{ HASIL PREDIKSI 4 MFs } \\
\cline { 3 - 9 } & 2015 & TRIAGL & Optim & TRAPES & Optim & GBELL & Optim & GAUSS & Optim \\
\hline 1 & -45.37 & -45.37 & $100 \%$ & -45.37 & $100 \%$ & -43.92 & $97 \%$ & -45.37 & $100 \%$ \\
\hline 2 & -26.54 & -26.54 & $100 \%$ & -26.54 & $100 \%$ & -26.44 & $100 \%$ & -26.57 & $100 \%$ \\
\hline 3 & -15.42 & -15.42 & $100 \%$ & -15.42 & $100 \%$ & -15.31 & $99 \%$ & -15.42 & $100 \%$ \\
\hline 4 & -9.77 & -9.77 & $100 \%$ & -9.77 & $100 \%$ & -9.80 & $100 \%$ & -9.77 & $100 \%$ \\
\hline 5 & -9.24 & -9.24 & $100 \%$ & -9.24 & $100 \%$ & -9.22 & $100 \%$ & -9.26 & $100 \%$ \\
\hline 6 & -8.77 & -8.77 & $100 \%$ & -8.80 & $100 \%$ & -8.70 & $99 \%$ & -8.77 & $100 \%$ \\
\hline 7 & -7.87 & -7.87 & $100 \%$ & -7.87 & $100 \%$ & -7.87 & $100 \%$ & -7.87 & $100 \%$ \\
\hline 8 & -5.53 & -5.53 & $100 \%$ & -5.53 & $100 \%$ & -5.53 & $100 \%$ & -6.33 & $114 \%$ \\
\hline 9 & -4.01 & -4.01 & $100 \%$ & -4.00 & $100 \%$ & -3.28 & $82 \%$ & -4.15 & $103 \%$ \\
\hline 10 & -0.18 & -0.19 & $106 \%$ & -0.18 & $100 \%$ & -0.18 & $100 \%$ & -0.21 & $117 \%$ \\
\hline 11 & 1.00 & 1.00 & $100 \%$ & -1.30 & $-130 \%$ & -2.81 & $-281 \%$ & 5.02 & $501 \%$ \\
\hline 12 & 1.01 & 1.01 & $100 \%$ & -2.45 & $-243 \%$ & 0.00 & $0 \%$ & 0.00 & $0 \%$ \\
\hline 13 & 0.23 & 0.23 & $99 \%$ & 0.22 & $96 \%$ & 0.24 & $104 \%$ & 0.23 & $99 \%$ \\
\hline 14 & 0.94 & 0.95 & $101 \%$ & 2.13 & $227 \%$ & 0.94 & $100 \%$ & 0.94 & $100 \%$ \\
\hline 15 & 2.75 & 2.74 & $100 \%$ & 2.25 & $82 \%$ & 2.71 & $99 \%$ & 2.70 & $98 \%$ \\
\hline 16 & 5.41 & 5.41 & $100 \%$ & 8.73 & $161 \%$ & 5.41 & $100 \%$ & 5.34 & $99 \%$ \\
\hline 17 & 5.95 & 5.95 & $100 \%$ & 14.77 & $248 \%$ & 5.97 & $100 \%$ & 5.55 & $93 \%$ \\
\hline 18 & 6.59 & 6.59 & $100 \%$ & 4.22 & $64 \%$ & 6.62 & $100 \%$ & 6.60 & $100 \%$ \\
\hline 19 & 7.56 & 7.56 & $100 \%$ & 7.56 & $100 \%$ & 7.58 & $100 \%$ & 6.52 & $86 \%$ \\
\hline
\end{tabular}




\begin{tabular}{|c|c|c|c|c|c|c|c|c|c|}
\hline \multirow{2}{*}{ No. } & \multirow{2}{*}{$\begin{array}{c}x(t-p) \\
2015\end{array}$} & \multicolumn{8}{|c|}{ HASIL PREDIKSI 4 MFS } \\
\hline & & TRIAGL & Optim & TRAPES & Optim & GBELL & Optim & GAUSS & Optim \\
\hline 20 & 8.20 & 8.20 & $100 \%$ & 8.21 & $100 \%$ & 8.48 & $103 \%$ & 8.17 & $100 \%$ \\
\hline 21 & 8.49 & 8.49 & $100 \%$ & 7.93 & $93 \%$ & 8.48 & $100 \%$ & 8.29 & $98 \%$ \\
\hline 22 & 9.01 & 9.01 & $100 \%$ & 11.11 & $123 \%$ & 9.06 & $101 \%$ & 8.96 & $99 \%$ \\
\hline 23 & 10.36 & 10.37 & $100 \%$ & 11.56 & $112 \%$ & 10.37 & $100 \%$ & 10.15 & $98 \%$ \\
\hline 24 & 10.80 & 10.80 & $100 \%$ & 11.17 & $103 \%$ & 10.83 & $100 \%$ & 10.76 & $100 \%$ \\
\hline 25 & 11.65 & 11.66 & $100 \%$ & 15.21 & $131 \%$ & 11.97 & $103 \%$ & 12.09 & $104 \%$ \\
\hline 26 & 12.34 & 12.34 & $100 \%$ & 14.18 & $115 \%$ & 12.23 & $99 \%$ & 11.89 & $96 \%$ \\
\hline 27 & 13.32 & 13.32 & $100 \%$ & 13.88 & $104 \%$ & 13.32 & $100 \%$ & 12.96 & $97 \%$ \\
\hline 28 & 14.41 & 14.41 & $100 \%$ & 14.20 & $99 \%$ & 14.42 & $100 \%$ & 14.34 & $100 \%$ \\
\hline 29 & 14.44 & 14.43 & $100 \%$ & 9.72 & $67 \%$ & 14.46 & $100 \%$ & 14.39 & $100 \%$ \\
\hline 30 & 14.53 & 14.53 & $100 \%$ & 14.53 & $100 \%$ & 14.51 & $100 \%$ & 14.35 & $99 \%$ \\
\hline 31 & 14.59 & 14.59 & $100 \%$ & 8.25 & $57 \%$ & 14.60 & $100 \%$ & 14.10 & $97 \%$ \\
\hline 32 & 14.81 & 14.81 & $100 \%$ & 14.79 & $100 \%$ & 14.82 & $100 \%$ & 14.73 & $99 \%$ \\
\hline 33 & 17.70 & 17.70 & $100 \%$ & 15.89 & $90 \%$ & 15.95 & $90 \%$ & 17.15 & $97 \%$ \\
\hline 34 & 17.84 & 17.85 & $100 \%$ & 12.35 & $69 \%$ & 17.57 & $98 \%$ & 17.84 & $100 \%$ \\
\hline 35 & 18.25 & 18.25 & $100 \%$ & 16.31 & $89 \%$ & 18.24 & $100 \%$ & 17.70 & $97 \%$ \\
\hline 36 & 19.35 & 19.35 & $100 \%$ & 19.37 & $100 \%$ & 19.29 & $100 \%$ & 19.34 & $100 \%$ \\
\hline 37 & 20.11 & 20.11 & $100 \%$ & 16.87 & $84 \%$ & 20.10 & $100 \%$ & 19.96 & $99 \%$ \\
\hline 38 & 20.12 & 20.13 & $100 \%$ & 17.16 & $85 \%$ & 20.16 & $100 \%$ & 20.04 & $100 \%$ \\
\hline 39 & 21.93 & 21.93 & $100 \%$ & 20.06 & $91 \%$ & 20.92 & $95 \%$ & 21.33 & $97 \%$ \\
\hline 40 & 22.46 & 22.46 & $100 \%$ & 29.29 & $130 \%$ & 22.45 & $100 \%$ & 22.09 & $98 \%$ \\
\hline 41 & 24.96 & 24.96 & $100 \%$ & 21.08 & $84 \%$ & 24.94 & $100 \%$ & 24.72 & $99 \%$ \\
\hline 42 & 32.37 & 32.37 & $100 \%$ & 32.37 & $100 \%$ & 31.75 & $98 \%$ & 32.37 & $100 \%$ \\
\hline 43 & 43.69 & 43.69 & $100 \%$ & 43.68 & $100 \%$ & 43.75 & $100 \%$ & 43.69 & $100 \%$ \\
\hline 44 & 44.57 & 44.57 & $100 \%$ & 44.57 & $100 \%$ & 44.64 & $100 \%$ & 45.30 & $102 \%$ \\
\hline 45 & 90.84 & 90.84 & $100 \%$ & 89.77 & $99 \%$ & 90.84 & $100 \%$ & 90.82 & $100 \%$ \\
\hline avg & 10.00 & 10.00 & $100 \%$ & 9.71 & $92 \%$ & 9.88 & $89 \%$ & 9.93 & $106 \%$ \\
\hline
\end{tabular}

Pada prediksi tahun kedepan dari titik " $t$ " 2014, dan prediksi " $p=1$ " tahun 2015 mengunakan data input periodikal 2011, 2012, 2013, 2014. Diperoleh hasil rata-rata perhitungan profitabilitas tahun $2015=9,95 \%$. Hasil rata-rata nilai prediksi fungsi keanggotaan Segitiga dengan tiga kategori dengan nilai prediksi yang optimal $100 \%$. Sedang hasil rata-rata nilai prediksi fungsi keanggotaan lainnya kurang optimal seperti : Trapesium $=9,71 \%$., Gauss $=9,93 \%$. dan Gbell $=9,88 \%$.

Perbandingan ROE 2015 dan Hasil Prediksi 4 MFs

\section{Daftar Pustaka}

[1] Idxfactbook, Jakarta Stock Exchange, Research and Product Development Division. 1997.

[2] Mardiyanto, Intisari Manajemen Keuangan: Teori,Soal dan Jawaban. Jakarta : Grasindo, 2009.

[3] D. C. S. Bisht and A. Jangid, "Discharge Modelling using Adaptive Neuro - Fuzzy Inference System," vol. 31, pp. 99-114, 2011.

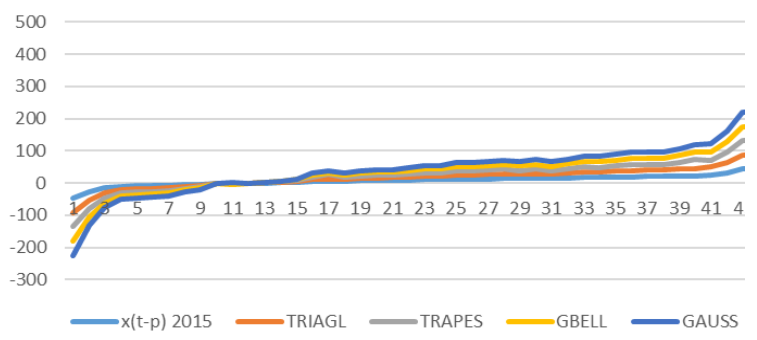

[4] U. P. Bandung, "Model Temporal Curah Hujan dan Debit Citarum Berbasis ANFIS," vol. 6 , no. 1, pp. 22-38, 2008.

[5] A. Yani, "Penerapan anfis untuk pengenalan sinyal ekg," no. 73 .

Gambar 2.11 Grafik perbandingan hasil prediksi 4 MFs dan ROE 2015

[6] B. Fatkhurrozi, M. A. Muslim, and D. R. Santoso, "Aktivitas Gunung Merapi," vol. 6, no. 2, pp. 113-118, 2012.

[7] O. Bachir and A. Zoubir, "Adaptive Neurofuzzy Inference System Based Control of puma 600 Robot Adaptive Neuro-fuzzy Inference System Based Control of Puma 600 Robot Manipulator,” no. January 2011, 2015. 
[8] I. Puspitasari and B. S. S. U, "Model Selection in Adaptive Neuro Fuzzy Inference System ( ANFIS ) by using Inference of R 2 Incremental for Time Series Forecasting," vol. 2, no. 2, pp. 38-42, 2013.

[9] Niswonger, Warren, Reeve, and Fess, Prinsip-Prinsip Akutansi, 19th ed. Penerbit Erlanga. Jakarta, 2004.

[10] B. Setyoko, "Pengaruh Profitabilitas, Kebijaksanaan Hutang, Kepemilikan Manajerial dan Ukuran Perusahaan Terhadap Nilai Perusahaan (Studi Empiris pada Perusahaan Manufaktur yang Terdaftar di Bursa Efek Indonesia Periode 20122014)," Universitas Muhammad Surakarta, 2017.

[11] Brigham, F. Eugene, Houston, and F. Joel, Dasar-dasar Manajemen Keuangan, 11th ed. Penerjemah Ali, 2011.

[12] A. Baroroh, "Analisis Multivariat dan Time Series dengan SPSS 21."

[13] K. Dewi and S. Hartati, Neuro-Fuzzy: Integrasi Sistem Fuzzy dan Jaringan Syaraf, 2nd ed. Yogyakarta: Graha Ilmu, 2006.

[14] J. R. Jang, "ANFIS Adaptive-Networkbased Fuzzy Inference System," no. June 1993, 2014.

[15] S. Kusumadewi and H. Purnomo, Aplikasi Logika Fuzzy untuk Pendukung Keputusan, 2nd ed. Graha Ilmu. Yogyakarta, 2010. 